\title{
La libertad religiosa y las libertades espirituales
}

\author{
José Antonio Souto Paz \\ Catedrático de la Universidad Complutense de Madrid
}

\begin{abstract}
SUMARIO: 1. ORÍGENES HISTÓRICOS DE LA LIBERTAD RELIGIOSA.- 2. LA COMUNIDAD POLÍ́TICA Y LAS CREENCIAS RELIGIOSAS. - 3. EL SIGNIFICADO CONSTITUCIONAL DE LA LIBERTAD RELIGIOSA.4. El Estado y las Comunidades Religiosas. a) Aconfesionalidad. b) Cooperación. c) Libertad y creencias religiosas.- 5. LA LIBERTAD Y LAS LIBERTADES ESPIRITUALES.
\end{abstract}

\section{ORÍGENES HISTÓRICOS DE LA LIBERTAD RELIGIOSA}

La Constitución eleva la libertad a la categoría de valor superior del ordenamiento jurídico ${ }^{1}$. Identifica, así, esta dimensión inherente a la dignidad de la persona humana de una forma unitaria: la libertad. Más tarde, al desarrollar los derechos fundamentales y las libertades públicas, enumera diversas libertades, comenzando esta especialización por la libertad ideológica y religiosa. No existe, ciertamente, contradicción entre ambas denominaciones: la libertad es única, pero para garantizar aspectos concretos de la misma se hace especial hincapié en aquellos que, por vicisitudes históricas o por exigencias actuales, han merecido una protección específica y, en consecuencia, una mención especial.

Esta especialización de las libertades —como recuerda Jellinek ${ }^{2}$ - comienza, precisamente, con la libertad reli-

1 Art. $1,1 \mathrm{CE}$.

${ }^{2}$ La Declaración de los Derechos del hombre y del ciudadano, trad. de A. Posada, Madrid, 1908. 
giosa o de conciencia. Las circunstancias históricas concretas que motivaron la quiebra religiosa de la Cristiandad medieval, en los albores de la Edad Moderna, como consecuencia de las doctrinas reformadoras protestantes, tuvieron unas consecuencias políticas concretas, que se tradujeron en la entronización del principio de confesionalidad del Estado y la adopción de un régimen de intolerancia religiosa, que condujo a la persecución de los súbditos que profesaban cultos disidentes de la religión oficial.

Esta política religiosa de los Estados europeos transcendió del ámbito interno de cada uno de ellos para convertirse en un conflicto entre Estados, en guerras por motivos religiosos, que concluirán con la Paz de Westfalia (1648). Precisamente, como reacción a estos hechos surge la doctrina de la tolerancia, los tratados de paz con cláusulas de tolerancia para los disidentes y, en definitiva, la defensa, dentro de la unidad religiosa de cada reino, de un status de tolerancia para los disidentes ${ }^{3}$.

La doctrina de la tolerancia conducirá al reconocimiento del derecho de libertad religiosa o de conciencia. Su proclamación oficial corresponderá a la colonia americana de Virginia que, en su Declaración de Derechos de 1776, reconoce: "que la religión, o los deberes que tenemos para con nuestro Creador, y la manera de cumplirlos, sólo pueden regirse por la razón y la convicción, no por la fuerza y la violencia; en consecuencia, todos los hombres tienen igual derecho al libre ejercicio de la religión de acuerdo con el dictamen de su conciencia"4.

Esta declaración hay que situarla en el ámbito de las doctrinas contractualistas y en el reconocimiento de que "todos los hombres son por naturaleza igualmente libres e independientes y tienen ciertos derechos innatos, de los

${ }^{3}$ Entre otros tratados internacionales, cabe citar el Tratado de Oliva, a favor de los católicos en Livonia, tras su cesión a Suecia por Polonia (1660); el Tratado de Nimega entre Francia y España (1678); el Tratado de Rywick, a favor de los católicos en los territorios cedidos por Francia a Holanda (1679); el Tratado de París, entre Francia, España y Gran Bretaña, a favor de los católicos en los territorios canadienses cedidos a Francia.

${ }^{4}$ Art. XVI. 
que, cuando entran en sociedad, no pueden privar o desposeer a su posterioridad por ningún pacto, a saber: el goce de la vida Y de la libertad"5. La libertad es un derecho innato e inalienable: pero, para evitar que se convierta en un concepto genérico y abstracto, se concreta y se pone especial énfasis en algunas manifestaciones de la libertad: la libertad religiosa o de conciencia: la libertad de prensa, la libertad política.

Es evidente que estas menciones obedecen a su ausencia en épocas inmediatamente anteriores. El contexto histórico, social y político determinan la aparición de las primeras libertades individuales especializadas. Pero, esta especialización no supone la quiebra de la unidad de la libertad, sino simplemente la mención de aquellas manifestaciones más significativas que, en un momento histórico determinado, han demandado una protección jurídica especial como consecuencia de su reciente privación o la amenaza de su agresión.

\section{LA COMUNIDAD POLÍTICA Y LAS CREENCIAS RELIGIOSAS}

¿Qué significado tiene fuera de ese contexto histórico la libertad religiosa? Durante siglos, - habría que remontarse, dentro de nuestro contexto cultural, a Grecia y a Roma-, las creencias religiosas han constituido un elemento conformador de la vida cultural de un pueblo, revistiendo el carácter de institución política. El individuo - como miembro de esa comunidad- tiene el deber cívico de profesar esas creencias; no hay esferas de libertad individual que autoricen la profesión de creencias contradictorias con las propias de la comunidad.

Esto significa que la concepción de la vida, la cosmovisión, es uno de los elementos identificativos de cada comunidad, que se expresa a través de un conjunto de creencias, costumbres, tradiciones, etc., legados por los antepasados, que constituyen la vida tradicional de un pueblo, es

5 Art. 1. 
decir, su propia cultura. Entre esos presupuestos culturales se han encontrado tradicionalmente las creencias religiosas. El reconocimiento de la libertad religiosa, como un derecho innato e inalienable, amplía el ámbito de los titulares de estas creencias. Además de las creencias comunitarias, se reconoce al individuo el derecho a elegir sus propias creencias.

Ello posibilitará, en principio, que el Estado, como expresión de la comunidad política, pueda ser confesional, es decir, pueda asumir unas creencias determinadas y, al mismo tiempo, reconozca el derecho a disentir, es decir, el derecho de cada ciudadano a tener sus propias creencias religiosas $^{6}$. Este moniismo comunidad-individuo, en el plano religioso, no ha desaparecido plenamente en la actualidad, pero se ha visto manifiestamente superado por la instauración del dualismo, cuya expresión más plena se encuentra en el principio del separatismo y su progresiva implantación en numerosos Estados.

Tal vez, el antecedente más significativo del separatismo Iglesia-Estado lo constituya la Primera Enmienda a la Constitución de los Estados Unidos de América (1791), en la que se establece una expresa prohibición al Congreso: "El Congreso no hará ley, alguna por la que se establezca una religión". Se establece, así, la prohibición de que el Estado asuma como propia una confesión o grupo religioso determinado, pero no significa que el Estado, en cuanto expresión del sentir común de la comunidad, excluya totalmente de su acervo ideológico las creencias religiosas. El separatismo en la Constitución americana es compatible con la referencia al "Dios de esa naturaleza" o al "Creador", así como a manifestar la "absoluta confianza en la protección de la Divina Providencia"7.

El vaciamiento de las creencias religiosas del contenido ideológico del Estado se va a producir a través del laicismo

${ }^{6}$ Conservan una religión oficial en Europa: Dinamarca, Finlandia, Inglaterra, Grecia, reconociendo, al mismo tiempo, el derecho de libertad religiosa.

7 Texto de la Declaración de Independencia de los Estados Unidos de América. v. MoRAN, G., La protección jurídica de la libertad religiosa en USA, Santiago de Compostela, 1989. 
y del ateísmo científico. El laicismo excluye del sustrato ideológico del Estado cualquier referencia religiosa y, por expansión, de cualquier manifestación religiosa de la vida pública, reduciendo el ámbito de las creencias religiosas a la autonomía individual, a la libre conciencia de los individuos. El ateísmo científico, no sólo elimina las creencias religiosas de la ideología del Estado, sino que asume -en sustitución de aquélla - una actitud antirreligiosa, una concepción ateísta beligerante que, en la experiencia histórica concreta, se ha traducido, frecuentemente, en la prohibición de la libertad religiosa, y en la persecución de personas e instituciones portadoras de creencias religiosas.

Estas actitudes -laicismo y ateísmo científico- no pueden considerarse como manifestaciones de la neutralidad ideológica del Estado en esta materia. Lejos de una actitud neutral han asumido y potenciado una determinada ideología — unas creencias no religiosas-, han actuado parcialmente en un intento de eliminar o suprimir las creencias religiosas presentes en la sociedad. Esta postura es claramente contraria al derecho de libertad religiosa, por lo que la exigencia de estas ideologías ha supuesto, en gran medida, la limitación y, en ocasiones la supresión, del contenido propio del derecho de libertad religiosa.

La superación de estas opciones ideológicas se ha producido con la adopción de la libertad como contenido ideológico del Estado y su proyección, a nivel individual, a través del reconocimiento y protección de la libertad de creencias religiosas o no religiosas, de actitudes teístas o ateístas, en definitiva del reconocimiento y consiguiente protección jurídica de la libre elección individual de su propia cosmovisión, independientemente de que su origen sea religioso, filosófico, ideológico, ético, humanitario o de cualquier otra naturaleza ${ }^{8}$.

Este reconocimiento a nivel individual y, la adopción, por parte del Estado, de la libertad como un valor superior

${ }^{8}$ La relación de estos textos y un análisis de los términos utilizados puede verse en Souto Galvan, E., El reconocimiento de la libertad religiosa en Naciones Unidas, Madrid, 1999. 
que informa el ordenamiento jurídico no supone un vaciamiento ideológico del Estado. Al contrario, la Constitución, como fórmula política, contiene "una expresión ideológica, fundada en valores, normativa e institucionalmente organizada, que descansa en una estructura socioeconómica"9. La Constitución se inspira, por tanto, en una ideología y se funda en unos valores, es decir, tiene una dimensión ideológica y una dimensión axiológica.

Esta doble dimensión constitucional no impide la neutralidad estatal respecto a opciones ideológicas o axiológicas individuales o partidarias, es decir, no obstaculiza la libertad ideológica de los individuos de los grupos, favoreciendo, por tanto, la existencia de un legítimo pluralismo social. Pero, por otra parte, constituye un límite a la propia libertad ideológica y religiosa, en cuanto esas creencias puedan entrar abiertamente en contradicción con los contenidos ideológicos y axiológicos constitucionales, garantizados por la cláusula del orden público protegido por la ley y, en concreto, por la salvaguarda de la seguridad pública, la salud pública y la moralidad pública.

La polaridad individuo-comunidad se traduce, así, en el reconocimiento del derecho a elegir individualmente su propia opción ideológica o religiosa, es decir, su propia cosmovisión. Por otra parte, la comunidad política, representada por el Estado, es portadora de una ideología y de una axiología, que pueden actuar como límite de las libertades individuales y colectivas, dando lugar a supuestos evidentes de colisión entre individuo y comunidad política.

\section{El SIGNIFICADO CONSTITUCIONAL DE LA LIBERTAD RELIGIOSA}

La Constitución garantiza la libertad ideológica, religiosa y de culto de los individuos y de las comunida-

9 LuCAS Verdu, P., Teoría de la Constitución como ciencia cultural, Madrid, 1997, p. 50. 
$\operatorname{des}^{10}$. La Declaración Universal de Derechos Humanos y otros Tratados Internacionales ratificados por España, que sirven de criterio de interpretación de los derechos fundamentales y, de las libertades reconocidas en la Constitución, según lo previsto en su art.10,2 utilizan una pluralidad de expresiones para referirse a esta materia: libertad de pensamiento, de conciencia, de religión, de creencias, de convicciones.

La diversidad terminológica utilizada, tanto por la Constitución ${ }^{11}$ como por los textos internacionales ${ }^{12}$, no pretenden describir un haz de libertades diferenciadas, sino referirse a una única libertad - la capacidad de autodeterminación individual en relación con su propia cosmovisión-, cuyo origen y fundamento puede encontrarse en un sistema filosófico, ideológico, ético, religioso, etc. Esta autonomía individual es garantizada constitucionalmente $y$, de manera igual, cualesquiera que sea el origen de ese ámbito en el que se albergan las creencias o las convicciones personales.

El significado, por tanto, de la libertad individual garantizado en el artículo 16 de la Constitución no puede li-

10 Art. 16, 1 y 2. Sobre los antecedentes y génesis de este texto constitucional, v. Amoros, J. J., La libertad religiosa en la Constitución Española de 1978, cit. Recientemente, J. R. POLO SABAU ha realizado un estudio original y fundamentado sobre esta cuestión, que permite aportar sobre la interpretación de este texto constitucional: "En torno a la naturaleza jurídica de la libertad ideológica y religiosa en la Constitución Española" en Revista de Estudios Políticos (Primera Época), núm. 128, Madrid, abril-mayo (2005), pp. 89-114.

${ }_{11}$ La Constitución utiliza las expresiones ideología, religión, creencias y culto (art. 16, 1 y 2). La utilización por la doctrina de esta variedad de expresiones puede verse en Llamazares, D., Derecho de la libertad de conciencia. 1. Libertad de conciencia y laicidad, Madrid, 1997; GonzÁLEZ DEL VALLE, J. M, Objeción de conciencia Y libertad religiosa e ideológica en las constituciones española, americana, declaraciones de la ONU y Convenio Europeo, con jurisprudencia, en "Revista de Derecho Privado", 1991, pp. 275-295; SouTo, J. A., Derecho Eclesiástico del Estado. El Derecho de la libertad de ideas y creencias, Madrid, 1995.

${ }^{12}$ La Declaración Universal de Derechos Humanos y el Pacto Internacional de Derechos Civiles y Políticos utilizan los términos pensamiento, conciencia, religión y creencias, mientras que la Convención Europea de Derechos Humanos y la Declaración sobre la eliminación de la intolerancia y la discriminación fundadas en la religión o las convicciones (1981) utilizan los mismos términos, pero sustituyendo creencias por convicciones. 
mitarse conceptualmente al derecho de libertad religiosa, sino que se refiere - en una interpretación integral de su contenido- a la libre autodeterminación del individuo en la elección de su propio concepto de la vida o de su propia cosmovisión, así, como de la libre adopción de decisiones existenciales ${ }^{13}$.

Aunque las circunstancias históricas han propiciado que el primer reconocimiento normativo de esta autonomía personal se hiciera a favor de la libertad religiosa, ello obedece a que, en aquel periodo histórico, la concepción de la vida o cosmovisión, era patrimonio exclusivo de las distintas religiones. El reconocimiento de la autonomía individual y la consiguiente libertad de creencias supone la ruptura del monopolio de las confesiones en esa materia y de la consiguiente utilización política de ese monopolio por el poder político.

Con el racionalismo y el advenimiento de las ideologías, nacidas con vocación de sustitución de las cosmovisiones religiosas, ese ámbito de autodeterminación personal traspasará el campo de lo religioso para abarcar, también, el mundo del pensamiento, de las concepciones filosóficas y, en general, de la propia concepción de la vida.

Las expresiones constitucionales libertad ideológica y libertad religiosa no son, pues, dos libertades alternativas, sino una sola libertad sobre un mismo contenido - la propia cosmovisión personal-, cuyo origen puede ser ideológico o religioso. Ciertamente, para garantizar este ámbito de autonomía personal, la Constitución utiliza estas dos expresiones - libertad ideológica y religiosa- que pretenden garantizar la propia concepción de la vida, cualesquiera que sea su origen: filosófico, ideológico, ético o religioso. En un intento de abarcar las diversas doctrinas, que puedan conformar las creencias o convicciones, se utiliza una pluralidad de adjetivos sin pretensión de exhaustividad. Así, a pesar de que con la expresión creencias se hace referencia tanto a las creencias religiosas como no religiosas,

13 RoBles, G., Los derechos fundamentales y la ética en la sociedad actual, Madrid, 1992. 
se ha llegado a exigir la inclusión en un texto internacional de la expresión convicciones, que, a juicio de algunos, parecía expresar mejor las manifestaciones ateístas, agnósticas y antirreligiosas ${ }^{14}$.

La elección de estas creencias o convicciones pertenece al ámbito de la autonomía personal garantizado jurídicamente. El derecho a tener unas creencias o convicciones implica el derecho a elegir o cambiar la propia cosmovisión y a gozar de inmunidad de coacción en ese proceso de elección, así como respecto a la libertad de declararla o negarse a declararla. Este conjunto de manifestaciones forman parte del contenido esencial del derecho de libertad de creencias.

Pero, no se agota ahí el contenido de este derecho. La libertad de creencias, calificada en el Preámbulo de la Declaración Universal de Derechos Humanos "como la aspiración más elevada del hombre", es la primera de las libertades llamadas por la doctrina francesa libertades espirituales o libertades del espíritu. La realización de esta libertad exige la adopción de una serie de libertades instrumentales que permitan la exteriorización de esta libertad. Así, la adopción de decisiones existenciales de acuerdo con las propias creencias constituye una exigencia propia del contenido de este derecho, que se manifiesta a través de la libertad de conciencia o libertad ética. Existe, por tanto, una relación causal necesaria entre libertad ideológica, libertad religiosa y libertad de conciencia, de tal manera que, aun no siendo citada expresamente en el texto constitucional, la propia jurisprudencia constitucional ha incluido en dicho texto, como una manifestación de la libertad ideológica y religiosa, a la libertad de conciencia ${ }^{15}$.

La dimensión ética, como dimensión específica de la autonomía personal, puede suscitar el conflicto entre libertad individual (libertad de conciencia) y los principios

${ }^{14}$ La defensa del término convicciones corrió a cargo de los representantes de los Estados socialistas, especialmente de la URSS y de la República de Bielorrusia.

${ }^{15}$ STC, 53/1985, de 11 de abril. 
axiológicos de la comunidad política (deberes legales y cláusula de orden público), que pueden expresarse, incluso, a través de una norma como deber legal del ciudadano. Ciertamente, el conflicto no se produce entre una norma religiosa y una norma estatal o entre una concepción filosófica o política y una norma estatal. El conflicto tiene lugar entre la propia conciencia individual, el imperativo de la conciencia, que no precisa de exigencias heterónomas, aunque pueda sentirse influida por ellas, y el imperativo legal. La reducción del problema al campo del derecho plantea problemas de difícil solución, por lo que es necesario continuar profundizando en el estudio de la dimensión jurídica del ámbito irrenunciable de protección de la autonomía ética individual y, además, es preciso determinar con la mayor nitidez posible los límites de la acción legislativa en este campo. No cabe la menor duda de que, en la actualidad, la colisión entre conciencia y ley se plantea como una de las cuestiones más apasionantes de la ciencia jurídica. Las diferentes manifestaciones de objeción de conciencia - más allá de la objeción de conciencia al servicio militar, reconocida constitucionalmente- revelan la variedad de conflictos que pueden producirse; así, aun no existiendo una regulación legal previa que ampare a los objetores, estos conflictos se plantean ante la propia jurisdicción ordinaria ${ }^{16}$.

El mundo de las ideas y creencias y de la ética individual se proyectan de manera especial en el campo de la educación. La formación de los nuevos ciudadanos en las costumbres, tradiciones y creencias de la comunidad, que fue una preocupación firme y certera de los filósofos clásicos y, más tarde, de los dirigentes religiosos, hoy se ha convertido en un reducto de la familia, de tal manera que

${ }_{16}$ Una sugestiva sistematización de estos supuestos puede verse en NAVARRo-VAlls, R., y MARTínez TorRon, J., Las objeciones de conciencia en el derecho español y comparado, Madrid, 1997. También, Palomino, R., Las objeciones de conciencia, Madrid, 1994; CAMARASA CARRILlO, J., La objeción de conciencia al servicio militar, Madrid, 1993. Acerca de la prestación social sustitutoria vid. AlENDA, M., El régimen penal de la prestación social de los objetores de conciencia, Valencia, 1996. 
la educación en los valores, es decir, la formación moral o religiosa es un derecho de los padres que, tanto en el ámbito doméstico como en el sistema educativo, tienen la facultad de elegir esa formación moral o religiosa de acuerdo con las propias convicciones ${ }^{17}$.

Este derecho presenta una doble dimensión: negativa y positiva. Por la primera está vedado al centro educativo o a los profesores cualquier actitud proselitista o de adoctrinamiento contrario a las convicciones previamente elegidas y que constituyen el contenido esencial de ese derecho de elección de la formación moral o religiosa. Pero, desde un punto de vista positivo, este derecho incluye la libertad de elección del centro educativo, de tal manera que los padres tienen derecho a elegir, entre los centros docentes, aquél cuyo ideario resulte más afín a sus propias creencias o convicciones ${ }^{18}$.

Este derecho-libertad no incluye, a nivel constitucional, un derecho prestacional exigible ante los poderes públicos. La financiación pública de la enseñanza privada, que haga realidad la libertad de educación, o de la enseñanza moral o religiosa propia de cada alumno, no constituye un deber prestacional para los poderes públicos, aunque, en virtud de lo dispuesto en el artículo 9.2 de la Constitución, puede asumir ese deber, en los términos previstos en las leyes o acuerdos, como ocurre en, el sistema educativo español ${ }^{19}$.

${ }^{17}$ La vinculación entre libertad de enseñanza y libre elección de la formación moral o religiosa ha sido expresada claramente en el Pacto Internacional de Derechos Económicos, Sociales y Culturales, cuyo art. 13, 3, dice: "Los Estados Partes en el presente Pacto se comprometen a respetar la libertad de los padres y, en su caso, de los tutores legales, de escoger para sus hijos o pupilos escuelas distintas de las creadas por las autoridades públicas, siempre que aquellas satisfagan las normas mínimas que el Estado prescriba o apruebe en materia de enseñanza, y de hacer que sus hijos o pupilos reciban la educación religiosa que esté de acuerdo con sus propias convicciones".

${ }^{18}$ La Ley Orgánica de 3 de julio, reguladora del derecho a la educación, reconoce el derecho de los padres o tutores a: "escoger centro docente distinto de los creados por los poderes públicos" y "que sus hijos reciban la formación moral o religiosa que esté de acuerdo con sus propias convicciones".

${ }_{19}$ La Constitución reconoce la libertad de enseñanza y, expresamente, la libertad de creación de centros docentes, así como autoriza la ayuda a aquellos que reúnan los requisitos que la ley establezca (Art. 27, 6, 7 y 9). La legislación 
Libertad de creencias (ideológica o religiosa), libertad ética o de conciencia y libertad de educación constituyen, así, junto con la libertad de expresión ${ }^{20}$, el núcleo fundamental de las libertades públicas que la doctrina francesa denomina libertades del espíritu ${ }^{21}$. La propia jurisprudencia constitucional española califica a la libertad de conciencia, de educación (enseñanza) ${ }^{22}$ y de expresión como protección de la libertad ideológica y religiosa ${ }^{23}$.

La comunicación entre estas manifestaciones concretas de la libertad personal se extiende a su dimensión colectiva. El derecho de asociación por motivos ideológicos o religiosos, aunque se rige por los principios generales del derecho asociativo, presenta características singulares, que han motivado la creación de una categoría específica en la doctrina alemana, que denomina a estas organizaciones empresas ideológicas o de tendencia. Su significado más relevante está constituido por el ideario o ideología de la organización que condiciona las relaciones de sus miembros con la organización, en aras a la armonía y consecución de los propios fines ideológicos de la organización, que justifican su existencia Y razón de ser. Entre estas empresas ideológicas se citan: los partidos políticos, los sindicatos, y las confesiones religiosas, a los que se han ido agregando, posteriormente, las empresas informativas $\mathrm{y}$, los centros de enseñanza ${ }^{24}$.

prevé la posibilidad de establecer conciertos con centros privados su financiación. Sobre esta cuestión, entre las publicaciones más recientes, v. SATORRAS, R. M., La libertad de enseñanza en la Constitución Española, Madrid, 1998; Polo SABAU, J. R., El régimen jurídico de la Universidad privada, Madrid, 1998; GARCÍA-PARDO, D., La libertad de enseñanza en la jurisprudencia del Tribunal Supremo, Madrid, 1998.

${ }^{20}$ FerReIro, J., Los límites de la libertad de expresión. La cuestión de los sentimientos religiosos, Madrid, 1996; RodRíGuez GARCíA, El control de los medios de comunicación, Madrid, 1998

${ }^{21}$ RoBert, J., Droits de l'homme et libertes fondamentales, Paris, 1996. La doctrina española suele utilizar la expresión libertad-participación, vid. ÁLVAREZ Conde, E., Curso de Derecho Constitucional, I, $2^{\mathrm{a}}$ ed., Madrid, 1996.

${ }^{22}$ Souto Galván, E., Derechos humanos, educación y libertad de creencias, Madrid, 2004.

${ }^{23}$ STC, 20/1990, de 15 de febrero.

${ }^{24}$ Souto Paz, J. A., Comunidad política y libertad de creencias, cit., p. 519. 


\section{El Estado y LAS COMUNIDADES RELigiosaS}

\section{a) Aconfesionalidad}

La Constitución declara expresamente que "ninguna confesión tendrá carácter estatal" ${ }^{25}$. Se ratifica, así, el principio del separatismo Estado-confesiones religiosas, cuyo antecedente normativo se encuentra, como hemos dicho, en la Primera Enmienda de la Constitución de los Estados Unidos. Se quiebra, de esta manera, en España una tradición secular de confesionalidad católica del Estado, sólo interrumpida por la Constitución de $1931^{26}$. Lo que en aquella ocasión constituyó un grave quebranto de la unidad política y social, en 1978 fue aceptado y asumido con absoluta normalidad. El consenso constitucional, al que se sumaron, además de las fuerzas políticas, las fuerzas sociales y, en este caso, la jerarquía de la Iglesia Católica, hicieron posible la aceptación del principio de aconfesionalidad constitucional, que, por otra parte, convergía con lo reclamado por la doctrina del Concilio Vaticano II, al proclamar la necesaria independencia de la Iglesia respecto de la sociedad política ${ }^{27}$.

La separación Iglesia-Estado, proclamada en la norma constitucional, es una garantía de neutralidad religiosa por parte del Estado y del eficaz funcionamiento del pluralismo religioso y de los principios de libertad e igualdad religiosa. Finalmente, supone la clausura de la instrumentación política de las creencias religiosas, según fórmulas

25 Art. 16, 3. Por su parte, la Unión Europea, en el Tratado de Amsterdam (1997) había incluido, también, la siguiente Declaración: "La Unión Europea respeta y no prejuzga el estatuto reconocido, en virtud del derecho nacional, a las iglesias y las asociaciones o comunidades religiosas en los Estados miembros. La Unión Europea respeta asimismo el estatuto de las organizaciones filosóficas y no confesionales" (Sobre esta cuestión v. RoBBERS, G., Estado e Iglesia en la Unión Europea, Madrid, 1996; FERRARI, S., e IBAN, I., Diritto e religione in Europa occidentale, 1997). La Constitutución Europea reitera el mismo principio, en su artículo I, 52. (vid. Souto Galván, E., El Estatuto de las Iglesias y de las Organizaciones no confesionales, en Comentarios a la Constitución Europea, libro II, dir. Álvarez Conde, E., y Garrido Mayol, V., Valencia, 2004, pp. 359-378).

26 Art. 3.

${ }^{27}$ Constitución Gaudium et Spes, núm. 76. 
variables en el tiempo, como institución política (mundo clásico y cesaropapismo medieval); como "instrumentum regni" (absolutismo político) o, simplemente, como esencia de la conciencia nacional garantizada políticamente ${ }^{28}$.

La separación Iglesia-Estado no debe identificarse con actitudes laicistas o antirreligiosas por parte del Estado. El vaciamiento de creencias religiosas de los contenidos ideológicos y axiológicos de la comunidad política no implica su sustitución por otros de contenido opuesto. La neutralidad se garantiza mejor y más adecuadamente cuando el Estado asume, como valor superior de un ordenamiento jurídico, la libertad. Esta opción, elegida por el constituyente español, permite conciliar la fórmula separatista con el mandato a los poderes públicos de que: "tendrán en cuenta las creencias religiosas de la sociedad española mantendrán las consiguientes relaciones de cooperación con la Iglesia Católica y las demás confesiones" 29 .

\section{b) Cooperación}

La fórmula constitucional permite conciliar el separatismo con la cooperación institucional entre el Estado y las confesiones religiosas. La traducción de este mandato constitucional se ha realizado a través de la Ley Orgánica 1980, de 5 de julio, de Libertad Religiosa que, además de reconocer los derechos antes mencionados, garantiza el derecho de las Iglesias, Confesiones y Comunidades religiosas a establecer lugares de culto o de reunión con fines religiosos, a designar y formar sus ministros, a designar y propagar su propio credo, y a mantener relaciones con sus

${ }^{28}$ Entre la numerosa bibliografía sobre esta cuestión, pueden consultarse las recientes aportaciones de RoCA, Ma. J., Origen de la competencia del poder civil sobre las Iglesias en las doctrinas protestantes: estudio histórico e interés actual, en FORO. Revista de Ciencias Jurídicas y Sociales, Nueva Época, Facultad de Derecho de la Universidad Complutense, núm. 0/2004, pp. 111-125 y VARela Suanzes, J., Política y Derecho en la Edad Media, en Revista Españla de Derecho Constitucional, año 17, núm. 49, enero-abril 1997, pp. 335-351.

${ }^{29}$ Art. 16.3. 
propias organizaciones o con otras confesiones religiosas, sea en territorio nacional o extranjero ${ }^{30}$.

Ninguna novedad especial refleja este apartado respecto al contenido de los derechos derivados del derecho de asociación. Sin embargo, con la intención, tal vez, de dar cumplimiento al mandato constitucional, en los términos indicados, o como consecuencia de exigencias históricas, el legislador ha considerado oportuno crear un régimen especial para las confesiones religiosas, que se lleva a cabo a través de un doble procedimiento: a) normativa unilateral; b) normativa bilateral.

La Ley de Libertad Religiosa ha creado un Registro Público en el Ministerio de Justicia para la inscripción de las Iglesias, Confesiones Comunidades religiosas y sus Federaciones. La inscripción en el Registro produce unos efectos jurídicos concretos y más amplios que los derivados del Registro común de Asociaciones: reconocimiento de personalidad jurídica, plena autonomía, cláusulas de salvaguarda de una identidad religiosa y carácter propio, etc. El problema principal que plantea este Registro reside en la propia calificación administrativa, respecto a la Asociación que solicita la inscripción en el Registro, en relación con el requisito de los fines religiosos, exigido en el artículo 5.2 de la ley. La interpretación administrativa de este requisito ha dado lugar a diversos recursos ante la jurisdicción ordinaria, con pronunciamientos diversos, que no han logrado una doctrina jurisprudencial común ${ }^{31}$. La cuestión es compleja, porque, al final, se trata de encontrar una respuesta adecuada a la pregunta ¿qué es una religión?, ¿qué son las creencias religiosas? Esta pregunta, aparentemente simple, fue planteada en el Parlamento Mundial de las Religiones y no fue posible encontrar una respuesta unánime ${ }^{32}$. Por otra parte, resulta difícil explicar la necesidad de crear un régimen especial distinto del

${ }^{30}$ Art. 16.3.

31 Además de diversas sentencias sobre esta cuestión de la Audiencia Nacional, cabe citar las Sentencias del Tribunal Supremo de 2 de noviembre de 1987 y la de 14 de junio de 1996.

${ }^{32}$ Kung, H., y Kuschel, K-J., Hacia una ética mundial, Madrid, 1994. 
que podría ser común a las diferentes entidades o empresas ideológicas ${ }^{33}$.

Pero, junto a este régimen unilateral, la ley autoriza la posibilidad de establecer Acuerdos o Convenios de cooperación con las Iglesias, Confesiones o Comunidades religiosas. Esta opción legislativa pretende traducir el supuesto constitucional "teniendo en cuenta las creencias religiosas existentes en España" y dar cumplimiento al mandato "mantendrán relaciones de cooperación", a través de la fórmula de los Acuerdos o Convenios. Los requisitos legales se circunscriben a que las confesiones estén inscritas y, que "por su ámbito y número de creyentes hayan alcanzado notorio arraigo en España" ${ }^{44}$. Este régimen bilateral permite la creación de un marco jurídico más amplio y beneficioso para las propias confesiones signatarias en orden a la concreción de sus propios fines religiosos.

Con anterioridad a la promulgación de la Ley de Libertad Religiosa, el Estado Español había suscrito, el 3 de enero de 1979, cuatro Acuerdos con la Iglesia Católica. A través de las cláusulas derogatorias se puede observar que dichos Acuerdos tienen una doble finalidad: a) proceder a la derogación del Concordato de 1953; b) crear un marco jurídico, cronológicamente, constitucional. A través de estos instrumentos bilaterales, con rango de tratados internacionales, se crea un marco jurídico para la Iglesia Católica distinto del común para las demás confesiones. Las diferencias se centran en los contenidos prestacionales que asume el Estado, especialmente, en el ámbito de la educación, cultura, asistencia religiosa y sostenimiento económico de la Iglesia Católica.

${ }^{33}$ Un análisis riguroso y completo sobre esta cuestión puede verse en PoLO SABÁU, J. R., ¿Derecho Eclesiástico del Estado o Libertades Públicas?, Málaga, 2002.

${ }^{34}$ Art. 7.1. Los cuatro Acuerdos han versado sobre: asuntos jurídicos; asuntos económicos; sobre enseñanza y asuntos culturales; sobre asistencia religiosa a las Fuerzas Armadas y sobre servicio militar de clérigos y religiosos. Entre una variada bibliografía sobre esta materia, v. Motilla, A., Los Acuerdos entre el Estado español y las confesiones religiosas en el Derecho español, Barcelona, 1985. 
Como contrapunto a estos Acuerdos, y, en cumplimiento de las previsiones contenidas en el artículo 7 de la Ley Orgánica de Libertad Religiosa, en 1992 se han firmado varios Acuerdos con las confesiones minoritarias: Entidades evangélicas, Comunidades israelitas, Comisión Islámica ${ }^{35}$. Estos Acuerdos pretenden ampliar el marco jurídico de estas confesiones, pero sin alcanzar los contenidos prestacionales del marco creado para la Iglesia Católica, especialmente, en el ámbito económico y educativo.

Habrá que complementar esta reseña, respecto al Derecho Acordado, con la referencia a los Acuerdos suscritos por las Comunidades Autónomas con la Iglesia Católica y otras confesiones, dentro del ámbito de su competencia y, singularmente, en asuntos culturales y protección del patrimonio artístico-religioso. Más singular resulta, sin embargo, el Convenio-marco suscrito entre la Generalitat de Cataluña y el Consejo Evangélico de Cataluña (21 de mayo de 1998), en el que, a la vista de los asuntos concertados, su contenido podría exceder el ámbito propio de las competencias de la Comunidad Autónoma para entrar en colisión con las competencias exclusivas del Estado en esta materia. En cualquier caso, se abre un abanico importante de posibilidades en este campo desde la perspectiva del Derecho Autonómico ${ }^{36}$.

35 Aprobadas por las leyes 24/1994, 25/1994 y 26/1994 respectivamente. Sobre el contenido de estos Acuerdos, v. Souto, J. A., Cooperación del Estado con las confesiones religiosas, en "Revista de la Facultad de Derecho de la Universidad Complutense de Madrid", n. 84, pp. 365-413. MANTECón, J., Los Acuerdos del Estado con las confesiones acatólicas, Jaén, 1995. Sobre la génesis de estos Acuerdos: FernÁndez-CoRonado, A., Estado y Confesiones religiosas: un nuevo modelo de relación, Madrid, 1995. Acerca de las cuestiones que suscitan estos Acuerdos vid. MARTín-Retortilo Baquer, L., Reflexiones sobre los Acuerdos de Cooperación del estado con las Federaciones Evangélica, Judía y Musulmana, en los diez años de su vigencia, en Revista Aragonesa de Administración Pública, núm. 23, 2003, pp. 11-40.

${ }^{36}$ Una visión de los diferentes problemas en esta materia v. Acuerdos del Estado español con confesiones religiosas minoritarias, coord. por V. REINA y M. A. FÉLIX, Madrid, 1996. Sobre la figura singular de los Convenios menores v. Roca, M. J., Naturaleza jurídica de los Convenios eclesiásticos menores, Pamplona, 1993. 


\section{c) Libertad y creencias religiosas}

El artículo 16 de la Constitución ha sido desarrollado parcialmente por la Ley Orgánica de Libertad Religiosa, de 5 de julio de 1980. Ha quedado excluido, en principio, de este texto legal la libertad ideológica y limitada la libertad de creencias a las creencias religiosas. En consecuencia, la Ley garantiza la libertad religiosa y de culto, ignorando la libertad ideológica, cuya equiparación con las citadas libertades ha sido expresamente reconocida en la Constitución, en los textos internacionales y, recientemente, en la Declaración sobre esta materia aprobada en el Tratado de Ámsterdam y en la Constitución Europea.

La Ley no ofrece un concepto o definición de la libertad religiosa y de culto; se limita a enumerar una serie de manifestaciones de esta libertad, protegidas por la ley y algunas actividades concretas excluidas del ámbito de protección de la misma. Entre estos últimos, incluye a "las actividades, finalidades y Entidades relacionadas con el estudio y experimentación de los fenómenos psíquicos o parapsicológicos o la difusión de valores humanísticos o espiritualistas u otros fines análogos ajenos a los religiosos" 37 .

Ciertamente, resulta una tarea difícil y compleja definir la libertad religiosa, dada la concepción plural que existe, a nivel universal, de qué es lo religioso. Es suficiente sobrevolar por las diferentes culturas y civilizaciones

37 Art. 3,2. El Grupo Andalucista presentó numerosas enmiendas, que, en general, presentaban como denominador común la ampliación del ámbito de la Ley a la libertad ideológica. Así se afirma que: "El término religioso tal y como está utilizado resulta equívoco, porque parece referirse sólo a los creyentes, y ya hemos mantenido que esta Ley debe amparar también a los que no lo son" (Enmienda núm.79). En la misma línea, propusieron la supresión del apartado 2 del artículo 3: "Resulta innecesario explicitar todo lo que queda fuera del ámbito de esta Ley. La práctica y difusión de valores humanísticos o espirituales no siempre es ajena al hecho religioso. Así, por ejemplo, el espiritismo tiene para sus adeptos un contenido indudablemente religioso. En cualquier caso son los individuos o asociaciones los que tienen que valorar si su actividad o profesión es o no es religiosa o está relacionada con el aspecto religioso y nunca la Administración la que determine estas cuestiones, ya que son realidades anteriores al reconocimiento por parte del Estado" (Enmienda, núm.78). 
para comprender la distinta concepción que existe de lo religioso, tanto en su dimensión histórica como universal. Sin embargo, la delimitación operada en la Ley obliga a intentar precisar el significado de lo religioso, pues así lo va a exigir la propia interpretación de algunas normas contenidas en el texto legal.

La propia norma da una definición negativa al excluir determinadas actividades del ámbito de protección de la Ley; pero, al mismo tiempo, ampara y protege la ausencia de creencias religiosas y, por consiguiente, las creencias agnósticas, ateístas y antirreligiosas ${ }^{38}$, como, por otra parte, han reconocido oportunamente diversas Declaraciones Internacionales ${ }^{39}$. En efecto, la equiparación entre religión y convicciones, a los efectos de protección jurídica, se extiende a la práctica del culto o la celebración de reuniones en relación con la religión o convicciones y de fundar y mantener lugares para estos fines; la de fundar y mantener instituciones de beneficencia o humanitarias adecuadas; la de confeccionar, adquirir y utilizar en cantidad suficiente los artículos y materiales necesarios para los ritos o costumbres de una religión o convicción; la de escribir, publicar y difundir publicaciones pertinentes en estas esferas; la de enseñar la religión o las convicciones en lugares aptos para estos fines; la de solicitar y recibir contribuciones voluntarias financieras y de otro tipo de particula-

${ }^{38} \mathrm{El}$ artículo 2, 1,a) reconoce el derecho de toda persona a "profesar las creencias religiosas que libremente elija o no profesar ninguna; cambiar de profesión o abandonar la que tenía; manifestar libremente sus propias creencias religiosas o la ausencia de las mismas, o abstenerse de declarar sobre ellas".

39 "El Derecho a la libertad de pensamiento, conciencia y religión (que incluye la libertad de creencias) en el art.18, es amplio y denso; abarca la libertad de pensamiento sobre cualquier tema, las convicciones personales y la adhesión a una religión o unas creencias ya sea manifestado de forma individual o colectiva. El Comité señala la atención de los Estados parte sobre el hecho de que la libertad de pensamiento y la libertad de conciencia se protegen en la misma medida que la libertad de religión o creencias... El art.18 protege las creencias deístas, no deístas y ateas, así como el derecho a no profesar ninguna religión o creencia. Los términos creencia y religión han de ser interpretados ampliamente" (Comentario oficial del Comité de Derechos Humanos de las Naciones Unidas al artículo 18 del Pacto Internacional de Derechos Civiles y Políticos, 20 de julio de 1993). 
res e instituciones; la de capacitar, nombrar, elegir y designar por sucesión los dirigentes que correspondan según las necesidades y normas de cualquier religión o convicción; la de observar días de descanso y de celebrar festividades y ceremonias de conformidad con los preceptos de una religión o convicción; la de establecer y mantener comunicaciones con individuos y comunidades acerca de cuestiones de religión o convicciones en el ámbito nacional $y$ en el internacional ${ }^{40}$.

La Declaración añade que: "Los derechos y libertades enunciados en la presente Declaración se concederán en la legislación nacional de manera tal que todos puedan disfrutar de ellos en la práctica"41. Aunque la fuerza vinculante de esta Declaración ${ }^{42}$ no es equivalente a la de un Convenio, sin embargo, la doctrina entiende que se trata de una interpretación auténtica del artículo 18 del Pacto Internacional de derechos civiles y políticos ${ }^{43}$, en cuyo caso tendría la misma fuerza vinculante que el propio Pacto Internacional.

La fórmula utilizada en los textos internacionales: libertad de pensamiento, conciencia y religión, creencias y

40 En la Declaración de Naciones Unidas sobre la eliminación de todas las formas de intolerancia y discriminación fundadas en la religión o las convicciones, de 1981, y, por tanto, posterior a la Ley española sobre libertad religiosa, se incluye, a continuación de la expresión religión, la expresión "convicciones de su elección". Esta frase se reproduce en todos los preceptos en que se garantizan las diferentes manifestaciones de la libertad religiosa, otorgando el mismo rango y protección a las "convicciones de su elección". De acuerdo con lo previsto en el artículo 10,2 de la Constitución, la Ley de libertad religiosa debería interpretarse de acuerdo con esta Declaración de Naciones Unidas y extender la protección reconocida a la libertad religiosa a la libertad de convicciones. Esta equiparación debería comprender, no sólo las libertades individuales, sino también las libertades colectivas, pues los derechos reconocidos en el artículo 6 de esta Declaración - libertades colectivas - se refiere a la libertad de pensamiento, de conciencia, de religión o de convicciones. Este conjunto de derechos reconocidos por motivos de religión o de convicciones están garantizados expresamente en el artículo 6 de la Declaración mencionada.

${ }^{41}$ Artículo 7.

${ }^{42}$ V. Sobre este punto, Souto GaLván, E., El reconocimiento de La Libertad religiosa en Naciones Unidas, cit.

${ }^{43}$ Martínez ToRrón, J., Normas de Derecho Eclesiástico, Granada, 1998, p. 73 . 
convicciones se refiere, en esta misma Declaración, a la libertad de cosmovisión - en los términos que hemos utilizado anteriormente-, pero no sólo en el plano individual, sino también en el colectivo. Los derechos reconocidos a las entidades religiosas deben extenderse, también, a las asociaciones ideológicas, filosóficas o éticas, expresión utilizada en los primeros borradores de la Constitución y, actualmente, en la Declaración adoptada por la Conferencia en el Tratado de Amsterdam, donde se dice que "la Unión Europea respeta y no prejuzga el estatuto reconocido, en virtud del derecho nacional, a las iglesias y las asociaciones o comunidades religiosas en los Estados miembros", respeto que extiende al "estatuto de las organizaciones filosóficas y no confesionales"44.

La equiparación de las organizaciones confesionales y de las organizaciones ideológicas o filosóficas no existe en la ley de libertad religiosa, que excluye expresamente a algunas organizaciones ideológicas e, indirectamente, a todas, al exigir el requisito de fines religiosos para la inscripción en el Registro de Entidades Religiosas. Esta exclusión ha reabierto la polémica sobre qué es lo religioso, produciéndose manifestaciones, al respecto, en el campo doctrinal y en la praxis administrativa y judicial ${ }^{45}$.

Las opiniones doctrinales al respecto han sido plurales. Así se ha afirmado que una organización tiene fines religiosos cuando existe: un conjunto de creencias, doctrinas y preceptos que se aceptan por los miembros con vinculaciones unitivas muy profundas de naturaleza religiosa; y una organización sobre normas propias, que requiere, en todo caso, la preexistencia de la organización,

44 Declaración sobre el Estatuto de las Iglesias y de las organizaciones no confesionales. Como ya se ha dicho antes, en la nota 24, la Constitución Europea incorpora el mismo texto contenido en la citada Declaración.

45 Sobre esta cuestión, vid., entre otros, Souto Galván, B., El reconocimiento estatal de las entidades religiosas, Madrid, 2000, Polo SABÁU, J. R., $\dot{i}$ Derecho Eclesiástico...?, cit. VEGA GuTIÉRREZ, A. Mª , El Registro de Entidades religiosas y la promoción de la libertad religiosa colectiva (A propósito de la STC 46/2001, de 5 de febrero).,en Repertorio Aranzadi del Tribunal Constitucional, febrero 2002, núm. 19 , pp. 25 y ss. 
anterior al reconocimiento; normativa propia; suficiente número de adeptos, suficiente para que activa y pasivamente pueda establecerse la correspondiente organización y ejercerse las respectivas funciones, etc. ${ }^{46}$. Otros autores requieren la existencia de unas comunidades con una finalidad religiosa, es decir, "un fondo doctrinal, que haga referencia a la divinidad, dotada de una praxis ritual y moral, y de una estructura permanente con normas de organización autónoma"47.

En fin, otros autores requieren la existencia de la creencia en un Ser superior, de una doctrina o dogma, de una moral, una organización, etc. ${ }^{48}$. Es evidente, en la mayoría de estas definiciones, la influencia del estereotipo de la Iglesia Católica, cuyos elementos integrantes parecen considerarse imprescindibles para que exista una entidad religiosa. Estas descripciones podrían ser válidas en un Estado confesional católico, que excluyera la presencia de otras confesiones religiosas, como ha ocurrido a lo largo de tantos siglos en España. Pero, si, por el contrario, se reconoce y garantiza la libertad religiosa, tal estereotipo es ciertamente inútil, porque no se corresponde con una concepción global y universal de lo religioso.

No faltan quienes apuntan, como elemento específico de lo religioso, el culto, llegando a afirmar que la existencia o no de culto permite distinguir el hecho religioso de las meras creencias filosóficas con contenidos metafísi$\cos ^{49}$. Esta diferencia tampoco es admitida en la doctrina de Naciones Unidas, que, entre las libertades dimanantes de la libertad religiosa reconoce: la de practicar el culto o de celebrar reuniones en relación con la religión o las

46 LóPez Alarcón, M., Dimensión orgánica de las confesiones religiosas en el Derecho Español, en "Ius Canonicum", 1980, p. 46.

47 Goti Ordeñana, J., Sistema de Derecho Eclesiástico, Parte Especial, San Sebastián, 1992, p. 16.

48 Bueno, S., El ámbito del amparo del Derecho de libertad religiosa y las Asociaciones, en Anuario de Derecho Eclesiástico del Estado, (1985), Madrid, pp. 185-205; Fuentes, G., Curso de Derecho Eclesiástico del Estado, Valencia, 1997, p. 202.

49 Bueno, S., op. cit., p. 186; también, González del Valle, J. M., Derecho Eclesiástico del Estado Español, Pamplona, 1993, p. 229. 
convicciones, y de fundar y mantener lugares para esos fines ${ }^{50}$.

Existe culto en organizaciones que no merecerían, según las anteriores definiciones, el carácter religioso, como pueden ser las sectas satánicas. Como explica G. FERRARI, "podemos afirmar que hablamos de satanismo cuando nos referimos a personas, grupos o movimientos que, de forma aislada o más o menos estructurada y organizada, practican algún tipo de culto (por ejemplo: adoración, veneración, evocación) del ser que en la Biblia se indica con los nombres de demonio, diablo o Satanás. En general, tal entidad es considerada por los satanistas como ser o fuerza metafísica; o como misterioso elemento innato en el ser humano; o energía natural desconocida, que se evoca bajo diversos nombres (por ejemplo: Lucifer) a través de particulares prácticas rituales" ${ }^{51}$.

Otras organizaciones, que autoexcluyen cualquier carácter religioso, practican un ritual y unas ceremonias típicamente cultuales y declaran un expreso reconocimiento de la divinidad. Así, la Masonería recoge en sus formularios rituales la siguiente declaración: "La Masonería admite en su seno a los hombres de todas las ideas religiosas. Reconoce la existencia de un principio regulador, absoluto e infinito, al que se da el nombre de GRAN ARQUITECTO DEL UNIVERSO, y comprendiendo que la Razón Humana debe ser el único medio de investigación de la Causa Suprema, respeta el medio que cada cual adopte para rendir culto a Dios. El hombre debe a Dios la existencia, la razón y el libre albedrío" 52 .

El culto no es, por tanto, un elemento exclusivo y diferenciador de las confesiones religiosas. Pero, es más, ni siquiera, algunas corrientes religiosas con una gran tradición y arraigo, incluyen, en su definición, una relación con la divinidad, ni la exigencia de un culto. A modo de ejem-

${ }^{50}$ Declaración sobre eliminación..., op. cit., art. 6,a).

${ }^{51}$ Ferrari, G., en AA.VV., Sectas satánicas y fe cristiana, Madrid, 1998, pp. 23 y 24 .

${ }^{52}$ Rito de iniciación en la Masonería, reproducido en LeRA, A. M. de, La masonería que vuelve, Barcelona, 1980. 
plo, "el budismo no es una religión con Dios. El budismo es una religión de la sabiduría, de la iluminación y de la compasión. Así como los creyentes en Dios creen en la posibilidad de la salvación por la confesión de los pecados y la vida de oración, así nosotros los budistas creemos en la posibilidad de la salvación y de la iluminación para todos los hombres por la eliminación de la mancha y de la mentira y por una vida de meditación" 53 .

La Administración ha elaborado, también, su propio concepto de confesión religiosa, manifestado, sin embargo, a través de rasgos diversos. Así, por ejemplo, en diversas Resoluciones de la Dirección General de Asuntos Religiosos, se exigen los siguientes requisitos:

a) Un cuerpo de doctrina propio que exprese las creencias religiosas que se profesan y que se desean transmitir a los demás;

b) una liturgia que recoja los ritos y ceremonias que constituyen el culto, con la existencia de lugares y ministros de culto en sus distintas denominaciones y funciones;

c) unos fines religiosos que respeten los límites al ejercicio del derecho de libertad religiosa, establecidos en el artículo 3 de la LOLR;

d) con carácter previo e indispensable, un número significativo de fieles, que constituyen el sustrato de una persona jurídica, toda vez que antes de calificar la naturaleza religiosa de la entidad peticionaria es necesario que se acredite la existencia de una verdadera y real entidad ${ }^{54}$.

Insistiendo en la interpretación de fines religiosos se afirma que: "la expresión común del hecho religioso se traduce en unas prácticas cúlticas y rituales que, para el entorno, son la muestra objetiva del hecho religioso. Las prác-

${ }^{53}$ Declaración del Ven. Samu Sunim del Templo del Budismo Zen de Chicago, recogido en "Hacia una Etica Mundial". Declaración del Parlamento de las Religiones del Mundo, ed. H. KüNG y K. J. KuscheL, Valladolid, 1994.

${ }_{54}$ Resoluciones de 15/9/1983; 29/1/1988; 25/6/1985; 18/4/1988; 25/5/1995. 
ticas religiosas pueden ser elaboradas o simples, aceptables desde el punto de vista moral o condenables, jerarquizadas o no, pero deben existir, si en la aceptación común de religión, ha de imponerse la presencia del hecho religioso" 55 .

A la vista de estos requisitos, resulta sorprendente encontrar una serie de Comunidades budistas inscritas en el Registro de Entidades Religiosas ${ }^{56}$. Teniendo en cuenta la anterior Declaración budista, estas comunidades no reúnen ninguno de los requisitos exigidos por la Administración. El ejemplo podría extenderse a otras entidades religiosas inscritas, que carecen de los requisitos tan solemnemente descritos por la Administración. Por el contrario, cumplen esos requisitos y tendrían que ser inscritas, si lo solicitasen, de acuerdo con los criterios establecidos por la propia Administración, las asociaciones masónicas o las sectas satánicas.

Tampoco los Tribunales, en los casos que ha tenido que conocer, se han recatado de pronunciarse sobre el concepto de religión. Así, acogiéndose a la definición de la Real Academia Española, se dice que "es un conjunto de creencias o dogmas acerca de la divinidad, de sentimientos de veneración y temor hacia ella, de normas morales para la conducta individual y social, y de prácticas rituales, principalmente la oración y el sacrificio para darle culto" 57 . En otro lugar, se dice que una entidad tiene fines religiosos "cuando su objetivo es agrupar a las personas que participan en unas mismas creencias sobre la divinidad, para considerar en común esa doctrina, orar y predicar sobre ella, así como realizar los actos de culto su sistema de creencias establece" 58 .

55 Resolución de 15 de enero de 1987.

${ }_{56}$ En la Guía de Entidades Religiosas de España, editada por el Ministerio de Justicia, Dirección General de Asuntos Religiosos, (Madrid, 1998), aparecen inscritas las siguientes comunidades budistas: Comunidad Religiosa Dag Shang Kagyu; Orden Budista Occidental; Comunidad Budista Soto Zen; Comunidad para la Preservación de la Tradición Mahayana; Karma Kagyu de Budismo Tibetano; Tashi Ling; Comunidad Budista Zen del Camino Abierto; Nichiren Shoshu Myoshoji; Sokka Gakkai de España.

57 Sentencias de la Audiencia Nacional de 23 de junio de 1988 y de 30 de septiembre de 1993.

${ }^{58}$ STS de 1 de marzo de 1994. 
Frente a esta actitud jurisprudencial, el Tribunal Constitucional ha obviado, recientemente, la cuestión conceptual de la religión y, por tanto, de las entidades religiosas, al declarar que "la articulación de un registro ordenado a dicha finalidad no habilita al estado para realizar una actividad de control de la legitimidad de las creencias religiosas, o sobre las distintas modalidades de expresión de las mismas, sino tan sólo la de comprobar, emanando a tal efecto un acto de mera constatación que no de calificación, que la entidad solicitante no es alguna de las excluidas por el artículo 3.2 de la LOLR, y que las actividades o conductas que se desarrollan para su práctica no atentan al derecho de los demás al ejercicio de sus libertades y derechos fundamentales, ni son contrarias a la seguridad, salud o moralidad públicas, como elementos en que se concreta el orden público protegido por la ley en una sociedad democrática, al que se refiere el artículo 16, 1 CE"59.

\section{LA LIBERTAD Y LAS LIBERTADES ESPIRITUALES}

Parece evidente que los intentos de definición de lo religioso se inspiran en un parámetro tradicional y local, dominado por la presencia, durante siglos, de una única confesión religiosa. La apelación al Diccionario de la Real Academia de la Lengua para describir qué se entiende por religión es una muestra inequívoca de una concepción sociológica dominante en nuestro país, pero, sin duda, alejada de un concepto más universalista de la religión.

El método hermenéutico que toma como punto de partida la historia, la cultura, la sociología propia para interpretar las instituciones jurídicas de un Estado puede dar

59 STC 46/2001, de 5 de febrero, Fundamento núm.8. Para una valoración doctrinal de esta Sentencia vid. Vega GutiérRez, A. Mª religiosas y la promoción de la libertad religiosa colectiva (A propósito de la STC 46/2001, de 5 de febrero), en Repertorio Aranzadi del Tribunal Constitucional, febrero 2002, núm. 19, pp. 25 y ss. y Polo SABAU, J. R., Acotaciones al régimen jurídico de las entidades religiosas a la luz de la garantía constitucional de la libertad de asociación, en Cuadernos de Derecho Público, 18 (2003) pp. 143 y ss. 
resultados positivos y permitir comprender y profundizar en las raíces, fundamentos y eficacia de esas instituciones. Sin embargo, cuando se trata de interpretar derechos y libertades fundamentales, que tienen un valor y un alcance universal, ese sistema resulta inadecuado. No es casualidad que, precisamente, al abordar esta cuestión, la Constitución española establezca, con carácter imperativo, que "las normas relativas a los derechos fundamentales y a las libertades que la Constitución reconoce se interpretarán de conformidad con la Declaración Universal de Derechos Humanos y los Tratados y Acuerdos internacionales sobre las mismas materias ratificados por España"60.

Tal vez, al ser un texto normativo tan conocido y tan citado, no haya sido correctamente interpretado. Las libertades públicas no pueden interpretarse únicamente de acuerdo con el significado cultural y sociológico o que la tradición histórico-jurídica española haya elaborado. La Constitución establece un mandato consistente en que dicha interpretación se realice de acuerdo con la Declaración Universal de Derechos Humanos y los demás tratados internacionales ratificados por España. "La Constitución - dice el Tribunal Constitucional- se inserta en un contexto internacional en materia de derechos fundamentales y libertades públicas, por lo que hay que interpretar sus normas en esta materia de conformidad con la Declaración Universal de Derechos Humanos y los tratados y acuerdos internacionales que menciona el precepto. Y... no sólo las normas contenidas en la Constitución, sino todas las del ordenamiento relativas a los derechos fundamentales y libertades públicas que reconoce la norma fundamental" 61 .

La interpretación de la libertad religiosa, regulada en la Ley Orgánica de libertad religiosa, no puede hacerse

60 Artículo 10,2. Sobre el origen y debate de este apartado en las Cortes Constituyentes, v. MARTín-Retortillo, L., Notas para la historia del apartado segundo del artículo 10 de la Constitución, en "la Europa de los derechos humanos", Madrid, 1998, pp. 178-192.

${ }^{61}$ STC 78/1982, F.J. $4^{\circ}$. 
descomponiendo su contenido en dos apartados (libertad y religión) e interpretando el significado religión de acuerdo con el sentir nacional tradicional. La libertad religiosa ha de interpretarse a la luz de la Declaración Universal de Derechos Humanos y de otros tratados, en los términos expresados con anterioridad, apoyándonos en los textos internacionales y en la interpretación oficial de los mismos realizada por los organismos internacionales ${ }^{62}$.

En consecuencia, y siguiendo el Comentario Oficial del Comité de Derechos Humanos de las Naciones Unidas ${ }^{63}$, es posible establecer los siguientes criterios hermenéuticos aplicables al artículo 16 de la Constitución española y a la Ley Orgánica de Libertad Religiosa:

1. El derecho a la libertad de pensamiento, conciencia y religión (que incluye la libertad de creencias) en el art.18, es amplio y denso; abarca la libertad de pensamiento sobre cualquier tema, las convicciones personales y la adhesión a una religión o a unas creencias ya sea manifestado de forma individual o colectiva.

2. La libertad de pensamiento y de conciencia se protegen en la misma medida que la libertad de religión y de creencias.

3. El carácter fundamental de estas libertades se refleja en que no pueden ser derogadas ni siquiera en situaciones de emergencia.

${ }^{62}$ Sobre este particular, vid. Souto Galván, E., El concepto de libertad religiosa en Naciones Unidas, en "Anuario de Derecho Eclesiástico del Estado", 1999. "El artículo 10,2... obliga a interpretar los correspondientes preceptos de ésta (la Constitución) de acuerdo con el contenido de dichos Tratados o Convenios, de modo que en la práctica este contenido se convierte en cierto modo en el contenido constitucionalmente declarado de los derechos y libertades que enuncia el capítulo segundo del Título I de nuestra Constitución..." (STC, 36/1991, F.J. $\left.5^{\circ}\right)$. En la misma línea se declara que: “... es lo cierto que los textos internacionales ratificados por España pueden desplegar ciertos efectos en relación con los derechos fundamentales, en cuanto pueden servir para configurar el sentido y alcance de los derechos recogidos en la Constitución como hemos mantenido, en virtud del artículo 10,2 CE, desde nuestra STC 38/1981, fundamentos jurídi$\cos 3^{\circ}$ y $4^{\circ \prime \prime}\left(\right.$ STC $254 / 1993$, F.J. $\left.6^{\circ}\right)$.

${ }^{63}$ Comentario oficial sobre el artículo 18 del Pacto Internacional de Derechos Civiles y Políticos (20 de julio de 1993). 
4. Las creencias deístas, no deístas y ateas, así como el derecho a no profesar ninguna religión o creencia están protegidas por el art.18.

5. Los términos creencia y religión han de ser interpretados ampliamente. No puede limitarse la aplicación del art.18 a las religiones tradicionales, o a las religiones o creencias con características institucionales o prácticas análogas a las de las religiones tradicionales.

Estos criterios cuestionan la interpretación administrativa y jurisprudencial, así como de una parte de la doctrina, que se viene haciendo de la libertad religiosa, ofreciendo una versión restringida y limitada de esta libertad, que pone en riesgo la seguridad jurídica de los individuos y de las comunidades. España, como Europa en general, escenario histórico de una confesión dominante y excluyente, observa con preocupación creciente la presencia de nuevos movimientos religiosos o ideológicos, que no encajan en los moldes tradicionales de lo religioso, y, con carácter preventivo y cautelar, se establecen mecanismos de control (Registro de Entidades Religiosas, Informes policiales e, incluso, la posible creación de un observatorio parlamentario sobre las sectas) de estos nuevos movimientos, denominados genéricamente sectas.

Esta tendencia presente en la vieja Europa, y en otros continentes, ha motivado que el propio Comité de Derechos Humanos muestre su preocupación por la tendencia a discriminar religiones o creencias por distintas razones, incluyendo el hecho de que se hayan implantado recientemente, o representen a minorías religiosas que pudieran ser objeto de hostilidad arte de la confesión religiosa mayoritaria ${ }^{64}$.

En conclusión, parece útil recordar, una vez más, que la libertad es una y única, y que las libertades especializadas son, tan sólo, manifestaciones parciales de esa única libertad. Por ello, el adjetivo que reciban cada una de esas li-

64 Ibídem, ap. 2. 
bertades no puede ser interpretado más allá de lo que es: un adjetivo, que expresa el ámbito sobre el que se extiende esa concreta libertad. Cuando se hace referencia a las libertades espirituales, es conveniente no olvidar que la primera manifestación de esas libertades reside en la libertad de cosmovisión, en cualquiera de sus acepciones parciales: libertad religiosa, de creencias, de convicciones, de pensamiento, etc. Las demás libertades espirituales: libertad ética o de conciencia, libertad de expresión, libertad de educación, libertad de asociación, reunión o manifestación, son libertades instrumentales para hacer efectiva la primera de esas libertades: la libertad de cosmovisión. 